\title{
Tumor Microenvironment and Pancreatic Cancer
}

\section{Shuo Wang and Chunying $\mathrm{Li}^{*}$}

Department of Biochemistry and Molecular Biology, Karmanos Cancer Insitute, Cardiovascular Research Institute, Wayne State University School of Medicine, Detroit, MI

Pancreatic cancer is the fourth leading cause of cancer-related deaths in both men and women (preceded by lung, prostate/breast and colon-rectum) in the United States, with a 5-year survival rate of less than 5\% [1]. Despite the rapid advances in diagnostic and operative techniques, the patient survival has little improvement in the last decade. Chemoresistance [2,3], early metastases, and late clinical presentation [4] are the major reasons for the poor clinical outcomes. This discouraging reality strongly suggests an urgent demand of new research directions and alternative/complementary approaches to improve the clinical outcome of pancreatic cancer.

Efforts through intensive genomic and histologic research over the last several decades have progressively increased our understanding of pancreatic carcinogenesis which is characterized by the accumulation of genetic alterations and concomitant morphological and histological changes in pancreatic ductal cells. However, the growth of our knowledge has not achieved the transition into more effective clinical approaches as expected. It has been documented that pancreatic cancer cells in vitro displayed a similar response to chemotherapeutic agents compared to the cell lines derived from other solid tumors [5]. However, pancreatic cancer patients have lower drug responses (e.g. paclitaxel) compared to breast and prostate patients [5], indicating that other cells in the pancreatic tumors also play important roles in chemoresistance. A major histopathological feature of pancreatic cancer is its prominent desmoplastic reaction, a pronounced increase in connective tissue around the tumor elements, and the stroma can form up to $90 \%$ of the tumor $[5,6]$. It has also been reported that pancreatic tumor desmoplasia correlates with its biological and clinical aggressiveness [6,7]. Therefore, attention has been steadily expanded to the tumor microenvironment including fibroblasts, peritumor nerves, endothelial cells, and macrophages [8], among which, pancreatic stellate cell (PSC) is considered to be a rising star in pancreatic cancer research.

Pancreatic stellate cells were first observed as fat-storing cells in pancreas with the functional similarity with hepatic stellate cells, counterpart cells in the liver [9]. PSCs were first isolated in 1998, and are the resident cells primarily located in peri-acinar, peri-ductal, and perivascular area of the pancreas [10,11]. First isolated, the PSCs were characterized in a quiescent state by the presence of intracellular fat droplets and absence of $\alpha$-smooth muscle actin ( $\alpha$-SMA). Activation of primary PSCs occurs in pancreatic injury or under cultivation, and PSCs attain a myofibroblast-like phenotype with the expression of a-SMA and extracellular matrix (ECM) proteins and disappearance of intracellular fat droplets $[10,11]$. An growing body of studies of primary PSCs in culture have identified several potential activators, such as growth factors (PDGF and TGF- $\beta 1$ ) $[12,13]$, cytokines (IL-1, IL-6, IL8 , and TNF- $\alpha$ ) $[14,15]$, angiotensin II [16], and reactive oxygen species (ROS) released by the recruited leukocytes in response to pancreatic injury [17]. Furthermore, evidence is accumulating to suggest the bidirectional interplay between pancreatic tumor cells and activated PSCs promotes the tumor progression [18-20]. Bachem et al. [11] has demonstrated the tumor growth rate is markedly increased when the PSCs are co-injected with the pancreatic cancer cells in vivo [19]. Pancreatic cancer cells attract and promote the activation, proliferation, and the capability to remodel the ECM of PSCs by secretion of the aforementioned mediators [18,19,21,22]. Meanwhile, PSCs secrete various growth factors (PDGF, IGF-1, EGF), ECM proteins (matrix metalloproteinases, collagen-I) which enhance the survival of the tumor cells by increased proliferation and reduced apoptosis [23,24], and promote the invasion of the tumor cells $[25,26]$. It has also been documented that PSCs promote epithelial-mesenchymal transition (EMT) via the production of increased fibrosis [27].

Several major signaling pathways involved in the functions of PSCs have been identified. MAPK/ERKs, initiated by growth factors and ethanol, have been suggested as key signal molecules regulating the functions of PSCs $[28,29]$. Activation of CXC-chemokine receptors is one of the up-stream signaling events of MAPK/ERKs signaling pathway. It has been reported that over expression of CXCchemokine receptors (such as CXCR2 and CXCR4) and their cognate ligands correlates with high tumor grade and stage in pancreatic adenocarcinoma [30-32]. Moreover, an increasing body of evidence has shown that blocking the CXC-chemokine receptor signaling represent an effective intervention to reduce proliferation [32,33], invasion [34], and tumor-induced angiogenesis $[32,34,35]$ both in vitro and in vivo. However, there are very few studies focusing on the CXC-chemokine signaling on PSC cells, which could improve our knowledge of the partially-understood mechanisms of the rapid tumor growth [19], enhanced epithelial-mesenchymal transition leading to metastasis [27], and poor delivery of chemotherapies [36] caused by PSCs and the prominent desmoplastic reactions.

A variety of PDZ (PSD-95/DlgA/ZO-1) domain-containing proteins (also referred to as PDZ scaffolding proteins) have been reported to nucleate the formation of compartmentalized multi-protein complexes that are critical for efficient and specific cell signaling [3742]. These PDZ scaffolding proteins preferentially localize at the membrane and interact with membrane proteins (such as receptors, channels) and their downstream effectors. Characterizing the PDZ domain-mediated chemokine receptor macromolecular signaling complex in PSCs could be an innovative way to study the molecular mechanisms of tumor-stroma interactions in pancreatic cancer, and furthermore could be an alternative way to improve the transition into more effective chemotherapies.

In summary, the patient survival in pancreatic cancer has been limitedly improved in the last decade, indicating that alternative approaches other than targeting cancer cells alone is in urgent demand. PSCs are the key mediators of the prominent desmoplastic reactions, a unique feature of pancreatic cancer. The interplay between pancreatic cancer cells and PSCs facilitates tumor progression, tumor-induced

${ }^{*}$ Corresponding author: Chunying $\mathrm{Li}, \mathrm{PhD}$, Department of Biochemistry and Molecular Biology, Karmanos Cancer Insitute, Cardiovascular Research Institute Wayne State University School of Medicine, Detroit, MI 48201. 540 E. Canfield Avenue, 5312 Scott Hall, Detroit, Ml 48201, Tel: +313577-4182; Fax: +313577-2765; E-mail: cl@med.wayne.edu

Received October 25, 2012; Accepted October 25, 2012; Published October 27 2012

Citation: Wang S, Li C (2012) Tumor Microenvironment and Pancreatic Cancer Mol Biol 1:e104. doi:10.4172/2168-9547.1000e104

Copyright: ( 2012 Wang S, et al. This is an open-access article distributed under the terms of the Creative Commons Attribution License, which permits unrestricted use, distribution, and reproduction in any medium, provided the original author and source are credited. 
angiogenesis, and metastasis. Various chemokine receptors and their cognate ligands are over expressed in the human pancreatic tumor, and correlates with the chemoresistance and poor prognosis. Targeting PDZ domain-mediated macromolecular complex of chemokine receptors in PSCs may represent a novel strategy to tackle pancreatic cancer

\section{References}

1. Siegel R, Naishadham D, Jemal A (2012) Cancer statistics, 2012. CA Cancer J Clin 62: 10-29.

2. Wang Z, Li Y, Ahmad A, Banerjee S, Azmi AS, et al. (2011) Pancreatic cancer: understanding and overcoming chemoresistance. Nat Rev Gastroentero Hepatol 8: 27-33.

3. Andersson R, Aho U, Nilsson BI, Peters GJ, Pastor-Anglada M, et al. (2009) Gemcitabine chemoresistance in pancreatic cancer: molecular mechanisms and potential solutions. Scand J Gastroenterol 44: 782-786.

4. Hidalgo M (2010) Pancreatic cancer. N Engl J Med 362: 1605-1617.

5. Li J, Wientjes MG, Au JL (2010) Pancreatic cancer: pathobiology, treatment options, and drug delivery. AAPS J 12: 223-232.

6. Neesse A, Michl P, Frese KK, Feig C, Cook N, et al. (2011) Stromal biology and therapy in pancreatic cancer. Gut 60: 861-868.

7. Mahadevan D, Von Hoff DD (2007) Tumor-stroma interactions in pancreatic ductal adenocarcinoma. Mol Cancer Ther 6: 1186-1197.

8. Farrow B, Albo D, Berger DH (2008) The role of the tumor microenvironment in the progression of pancreatic cancer. J Surg Res 149: 319-328.

9. Watari N, Hotta $Y$, Mabuchi $Y$ (1982) Morphological studies on a vitamin A-storing cell and its complex with macrophage observed in mouse pancreatic tissues following excess vitamin A administration. Okajimas Folia Anat Jpn 58 837-858.

10. Apte MV, Haber PS, Applegate TL, Norton ID, McCaughan GW, et al. (1998) Periacinar stellate shaped cells in rat pancreas: identification, isolation, and culture. Gut 43: 128-133.

11. Bachem MG, Schneider E, Gross H, Weidenbach H, Schmid RM, et al. (1998) Identification, culture, and characterization of pancreatic stellate cells in rats and humans. Gastroenterology 115: 421-432.

12. Luttenberger T, Schmid-Kotsas A, Menke A, Siech M, Beger H, et al. (2000) Platelet-derived growth factors stimulate proliferation and extracellular matrix synthesis of pancreatic stellate cells: implications in pathogenesis of pancreas fibrosis. Lab Invest 80: 47-55.

13. Shek FW, Benyon RC, Walker FM, McCrudden PR, Pender SL, et al. (2002) Expression of transforming growth factor-beta 1 by pancreatic stellate cells and its implications for matrix secretion and turnover in chronic pancreatitis. Am J Pathol 160: 1787-1798

14. Apte MV, Haber PS, Darby SJ, Rodgers SC, McCaughan GW, et al. (1999) Pancreatic stellate cells are activated by proinflammatory cytokines: implications for pancreatic fibrogenesis. Gut 44: 534-541.

15. Mews P, Phillips P, Fahmy R, Korsten M, Pirola R, et al. (2002) Pancreatic stellate cells respond to inflammatory cytokines: potential role in chronic pancreatitis. Gut 50: 535-541.

16. Hama K, Ohnishi H, Aoki H, Kita H, Yamamoto H, et al. (2006) Angiotensin II promotes the proliferation of activated pancreatic stellate cells by Smad7 induction through a protein kinase $\mathrm{C}$ pathway. Biochem Biophys Res Commun 340: $742-750$.

17. Masamune A, Watanabe T, Kikuta K, Satoh K, Shimosegawa T (2008) NADPH oxidase plays a crucial role in the activation of pancreatic stellate cells. Am J Physiol Gastrointest Liver Physiol 294: G99-G108.

18. Apte MV, Park S, Phillips PA, Santucci N, Goldstein D, et al. (2004) Desmoplastic reaction in pancreatic cancer: role of pancreatic stellate cells. Pancreas 29: 179-187.

19. Bachem MG, Schünemann M, Ramadani M, Siech M, Beger H, et al. (2005) Pancreatic carcinoma cells induce fibrosis by stimulating proliferation and matrix synthesis of stellate cells. Gastroenterology 128: 907-921.

20. Hwang RF, Moore T, Arumugam T, Ramachandran V, Amos KD, et al. (2008) Cancer-associated stromal fibroblasts promote pancreatic tumor progression. Cancer Res 68: 918-926.
21. Xu Z, Vonlaufen A, Phillips PA, Fiala-Beer E, Zhang X, et al (2010) Role of pancreatic stellate cells in pancreatic cancer metastasis. Am J Pathol 177: 2585-2596.

22. Vonlaufen A, Phillips PA, Xu Z, Goldstein D, Pirola RC, et al. (2008) Pancreatic stellate cells and pancreatic cancer cells: an unholy alliance. Cancer Res 68 : 7707-7710.

23. Edderkaoui M, Hong P, Vaquero EC, Lee JK, Fischer L, et al. (2005) Extracellula matrix stimulates reactive oxygen species production and increases pancreatic cancer cell survival through 5-lipoxygenase and NADPH oxidase. Am J Physio Gastrointest Liver Physiol 289: G1137-G1147.

24. Vaquero EC, Edderkaoui M, Pandol SJ, Gukovsky I, Gukovskaya AS (2004) Reactive oxygen species produced by $\mathrm{NAD}(\mathrm{P}) \mathrm{H}$ oxidase inhibit apoptosis in pancreatic cancer cells. J Biol Chem 279: 34643-34654.

25. Schneiderhan W, Diaz F, Fundel M, Zhou S, Siech M, et al. (2007) Pancreatic stellate cells are an important source of MMP-2 in human pancreatic cance and accelerate tumor progression in a murine xenograft model and CAM assay. J Cell Sci 120: 512-519.

26. Phillips PA, McCarroll JA, Park S, Wu MJ, Pirola R, et al. (2003) Rat pancreatic stellate cells secrete matrix metalloproteinases: implications for extracellular matrix turnover. Gut 52: 275-282

27. Kikuta K, Masamune A, Watanabe T, Ariga H, Itoh H, et al. (2010) Pancreatic stellate cells promote epithelial-mesenchymal transition in pancreatic cance cells. Biochem Biophys Res Commun 403: 380-384.

28. Ohnishi H, Miyata T, Yasuda H, Satoh Y, Hanatsuka K, et al. (2004) Distinct roles of Smad2-, Smad3-, and ERK-dependent pathways in transforming growth factor-beta1 regulation of pancreatic stellate cellular functions. J Biol Chem 279: 8873-8878

29. Kikuta K, Masamune A, Satoh M, Suzuki N, Satoh K, et al. (2006) Hydrogen peroxide activates activator protein-1 and mitogen-activated protein kinases in pancreatic stellate cells. Mol Cell Biochem 291: 11-20.

30. Hussain F, Wang J, Ahmed R, Guest SK, Lam EW, et al. (2010) The expression of IL-8 and IL-8 receptors in pancreatic adenocarcinomas and pancreatic neuroendocrine tumours. Cytokine 49: 134-140.

31. Liang JJ, Zhu S, Bruggeman R, Zaino RJ, Evans DB, et al. (2010) High levels of expression of human stromal cell-derived factor-1 are associated with worse prognosis in patients with stage II pancreatic ductal adenocarcinoma. Cancer epidemiology, biomarkers \& prevention. Cancer Epidemiol Biomarkers Prev 19: $2598-2604$

32. Li A, King J, Moro A, Sugi MD, Dawson DW, et al. (2011) Overexpression of CXCL5 is associated with poor survival in patients with pancreatic cancer. Am J Pathol 178: 1340-1349.

33. Takamori H, Oades ZG, Hoch OC, Burger M, Schraufstatter IU (2000) Autocrine growth effect of IL-8 and GROalpha on a human pancreatic cancer cell line Capan-1. Pancreas 21: 52-56.

34. Matsuo Y, Ochi N, Sawai H, Yasuda A, Takahashi H, et al. (2009) CXCL8/ IL-8 and CXCL12/SDF-1alpha co-operatively promote invasiveness and angiogenesis in pancreatic cancer. Int J Cancer 124: 853-861.

35. Matsuo Y, Raimondo M, Woodward TA, Wallace MB, Gill KR, et al. (2009) CXC-chemokine/CXCR2 biological axis promotes angiogenesis in vitro and in vivo in pancreatic cancer. Int J Cancer 125: 1027-1037.

36. Olive KP, Jacobetz MA, Davidson CJ, Gopinathan A, Mclntyre D, et al. (2009) Inhibition of Hedgehog signaling enhances delivery of chemotherapy in a mouse model of pancreatic cancer. Science 324: 1457-1461.

37. Wang S, Yue H, Derin RB, Guggino WB, Li M (2000) Accessory protein facilitated CFTR-CFTR interaction, a molecular mechanism to potentiate the chloride channel activity. Cell 103: 169-179.

38. Hall RA, Ostedgaard LS, Premont RT, Blitzer JT, Rahman N, et al. (1998) A $C$-terminal motif found in the $\beta_{2}$-adrenergic receptor, P2Y1 receptor and cystic fibrosis transmembrane conductance regulator determines binding to the $\mathrm{Na}+$ $\mathrm{H}+$ exchanger regulatory factor family of PDZ proteins. Proceedings of the National Academy of Sciences of the United States of America 25: 8496-8501.

39. Naren AP, Cobb B, Li C, Roy K, Nelson D, et al. (2003) A macromolecula complex of beta 2 adrenergic receptor, CFTR, and ezrin/radixin/moesin-binding phosphoprotein 50 is regulated by PKA. Proc Natl Acad Sci U S A 100: 342 346.

40. Li C, Dandridge KS, Di A, Marrs KL, Harris EL, et al. (2005) Lysophosphatidic 
acid inhibits cholera toxin-induced secretory diarrhea through CFTR-dependent protein interactions. J Exp Med 202: 975-986.

41. Wu Y, Wang S, Farooq SM, Castelvetere MP, Hou Y, et al. (2012) A chemokine receptor CXCR2 macromolecular complex regulates neutrophil functions in inflammatory diseases. J Biol Chem 287: 5744-5755.

42. Wu Y, Wang S, Li C (2012) In vitro analysis of PDZ-dependent CFTR macromolecular signaling complexes. J Vis Exp. 